\title{
Legal Offerings Increase the Effectiveness of Determination of Coercive Money and Administrative Sanctions on State Administrative Decisions
}

\author{
Mutiara Hamdalah Munandar \\ Faculty of Law, Universitas Negeri Semarang, Semarang, Central Java, Indonesia \\ Email: mutiarahamdalah@students.unnes.ac.id \\ ORCID Link: https://orcid.org/0000-0003-4604-3519 \\ Yudha Chandra Arwana \\ Faculty of Law, Universitas Negeri Semarang, Semarang, Central Java, Indonesia
}

Asna Yusrina

Faculty of Creative Media, Multimedia University Melaka Campus, Melaka, Malaysia

\section{Citation:}

Munandar, M.H., Arwana, Y.C., Yusrina, A. (2021). Legal Offerings Increase the Effectiveness of Determination of Coercive Money and Administrative Sanctions on State Administrative Decisions, Lex Scientia Law Review, 5(1), 83-96, doi:https://doi.org/10.15294/lesre v.v5i1.46287

\section{History of Article}

Received: April 10, 2021

Revised: May 18, 2021

Accepted: May 27, 2021

(C) The Author(s)

\section{(c) (i) 8 (2)}

This work is licensed under a Creative Commons Attribution-NonCommercialShareAlike 4.0 International License.

\begin{abstract}
This paper is titled Legal Offers In Improving the Effectiveness of Forced Money Determination Efforts and Administrative Sanctions On the warning of a valid verdict that is not carried out by the defendant. The assessment of the formulation of the problem in this study is how the legal culture in Indonesia to the application of Article 116 paragraph (4) of Law No. 51 of 2009 on State Administrative Justice. In this paper the author also provides an understanding of the comparison of the State Administrative Law system (Indonesia) with Verwaltungsgerecht (Germany) in order to realize legal justice for the community. By using paradigms in terms of epistemological and axological aspects. In the implementation has not been found a special authority in overseeing the existence of the State Administrative Decision (KTUN) that has been validly decided by the judge, there are still some cases of defendants who do not
\end{abstract}


All writings published in this journal are personal views of the authors and do not represent the views of this journal and the author's affiliated institutions.

Lex Scientia Law Review published by Faculty of Law, Universitas Negeri Semarang, Indonesia in collaboration of UKM Lex Scientia. Published biannually every May and November. carry out the warning of the verdict against the verdict. So the defendant must pay forced money or administrative sanctions against it. From these cases, there should be special authority in supervising the KTUN that has been decided by the judge. The author in this paper offers a legal offer to improve the effectiveness in the implementation of the KTUN in improving legal certainty and guarantee of legal protection in the field of State Administrative Justice. The authors of this paper use descriptive doctrinal research methods, descriptive legal research that explains what should be communicated with the law in the review of das sollen and das sein.

\section{KEYWORDS}

Administrative Sanctions; Forced Money; Legal Offers; Legal Protection; State Administrative Decision (KTUN)

\section{INTRODUCTION}

Law has a purpose in fulfilling people's rights, which is stated in the theory of legal objectives according to Gustave Radbruch in his book entitled "The Legal Philosophies of Lask, Radbruch, and Dobin," which was published in $1950 .{ }^{1}$ Until now, this legal theory is still used as a reference for the achievement of a complete legal function in the legal society.

"The idea of law is defined through a triad of justice, utility, and certainty".

Radbruch argues that Law must have objectives that oblige these objectives to be achieved, these goals are called the fundamental values of law, namely:

1. Justice;

2. Benefits; and

3. Legal certainty.

These goals should be the ideal values applied to society. However, something that is considered ideal by philosophers and law enforcers is different between das sollen and das sein. In the book "Substantial Justice Trims the Chain of Legal Bureaucracy," written by Muhammad Taufiq, Taufiq thinks that the objectives of the law cannot be implemented all or all of them. In reality, the implementation of these objectives can only be carried out by one to two values. That is, it can only benefit or justice and benefit, or justice

\footnotetext{
${ }^{1}$ Lask, Radbruch, and Dabin, The Legal Philosophies of Lask, Radbruch, and Dabin. Translate by Kurt Will, etc, Harvards University press, Cambrigg, Massacilusetts, 1950.
} 
and legal certainty, or anything else. ${ }^{2}$ So it is almost impossible if the objective of the law is carried out perfectly on these three values.

The implementation of the legal objective value is used in the State Administrative Court (hereinafter as PERATUN) system in various countries, including Indonesia which has the same judiciary. As explained in Article 1 number 10 of Law Number 51 of 2009 concerning State Administrative Courts regarding state administrative disputes, the definition of state administration dispute is a dispute involving individual persons or civil legal entities with state administrative bodies or officials. The dispute arose as a result of the determination of the state administration sector between them. That is, the emergence of the dispute from the government or officials to the society as described in that article. As described in this explanation, sometimes many people cheating on society. In this case, the fraud originates from the government in this article it is mentioned as an agency/official of State Administration (TUN). This is the main objective of PERATUN.

However, even though the plaintiff has sued to get their rights, there are still judges' decisions that have not been implemented or have not been implemented by the defendants at all. Although the defendant was supposed to pay forced money or administrative sanctions as stated in Article 116 paragraph (4) of Law No.51 of 2009 concerning Amendments of Law Number 5 of 1986 concerning State Administrative Courts, these efforts were still ineffective because there was no supervision after the decision is stipulated. Therefore, it is necessary to have special authority on law enforcers in the PERATUN, which aims to supervise the verdict that the judge has determined.

In this paper, the authors found that several problems occur in the PERATUN system that must be addressed to achieve legal certainty in fulfilling society rights and guarantees of legal protection in the PERATUN system. The author wants to offer legal reforms to the PERATUN system. The author uses the legal philosophy paradigm of positivism, axiology, and epistemology in law. The author also relates the offer in terms of the current state administrative law culture. The purpose of this paper is an effort to enforce forced money and administrative sanctions on defendants who do not carry out the verdict that can be handled properly by regulations and/or additional authority possessed by the State Administrative Court (PTUN).

\footnotetext{
2 Muhammad Taufik, Keadilan Substansial Memangkas Rantai Birokrasi Hukum, First Edition, Pustaka Pelajar, Yogyakarta, 2014, Pg. 161
} 


\section{METHOD}

In this research, the authors used descriptive doctrinal study. Legal research is descriptive, namely exposure that aims to obtain complete data regarding legal conditions at a particular time or legal events within society's scope.

In writing and compiling this research, the author applies the legal method, namely the normative juridical method which emphasizes the case study system on normative law in terms of products to the legal behavior of the society. ${ }^{3}$ In this research, the sources used came from relevant and related laws in the research conducted by the author. These sources are in the form of literature, scientific papers, and research results relevant to the author's research. After the aut hors collect the data that has been found, the analysis is collected and carried out by induction analysis, namely by reduction activities, presentation activities in this case the presentation of the research, and getting the conclusions needed in this study.

\section{RESULT AND DISCUSSION}

\section{A. Implementation of Forced Money Measures and Administrative Sanctions on Defendants who Fail to Carry Out the Decisions}

The administration of government in the Indonesian legal system is based on a principle called the principle of people's sovereignty and the rule of law. Therefore, all actions of the government and state apparatus in administrative decisions are required or required based on predetermined values, namely the sovereignty of the people and the law. Does the government or law enforcement apparatus have to be supervised by a special authority or institution that can oversee this matter? The answer is yes. Such supervision is part of the law that oversees the internal, political, and judicial control system which is carried out by a court, namely PERATUN. ${ }^{4}$

Before the existence of Law Number 51 of 2009 concerning State Administrative Courts, there was a law regulating the State Administrative Court, namely Law Number 5 of 1986 . The birth of this Law resulted from the legal need for the society to resolve disputes State Administration between the society or civil legal entities with State Administration officials. So as time goes by and the law is a public need in the rule of law, Law Number 5 of 1986 is amended to Law Number 51 of 2009 to regulate matters that have not been

\footnotetext{
${ }^{3}$ Ridwan Arifin, Waspiah Waspiah, \& Dian Latifiani, Penulisan Karya Ilmiah untuk Mahasiswa Hukum, BPFH UNNES, Semarang, 2018.

${ }_{4}^{4}$ Maridjo, Pengawasan Peradilan Tata Usaha Negara Terhadap Keputusan Tata Usaha Negara Dalam Mewujudkan Pemerintahan yang Baik, University Semarang, Semarang, 2016, p. 124.
} 
regulated in the State Administrative Court. ${ }^{5}$ PERATUN in our country, namely the state of Indonesia, is a court regarding administration with authority and can assess the validity of PERATUN decisions. This assessment is related to governance which is also carried out by the government. ${ }^{6}$

The existence of law implementation in the KTUN is actually a process of implementing the legal culture. According to Lawrence M. Friedmen ${ }^{7}$ in his book entitled American Law: An Introduction it is said that legal culture is divided into two, namely:

\section{External Legal Culture}

It is a legal culture that is contained in the general public system;

\section{Internal Legal Culture}

Namely, the legal culture that carries out its duties carried out by the society as a duty in carrying out the law.

Regarding this matter, Lawrence M. Friedmen emphasized that "we can distinguish between an external and an internal legal culture. The external legal culture is the legal culture of those members of society who perform specialized legal tasks. Every society has a legal culture but only societes with legal specialists have an internal legal culture". Legal culture is an opinion, habit, way of thinking and acting, both from the side of law enforcers and from the side of the society. For example, if people do not make it a habit to give bribes, law enforcement officials will also not be accustomed to asking for bribes. ${ }^{8}$ Likewise, if the law enforcement apparatus makes it a habit to firmly refuse any form of bribery, then the public will not dare to initiate the initiative to give bribes. Substance and apparatus are not sufficient for the functioning of the legal system. The discussion of legal culture is closely related to the law in the future. Because the discussion of legal culture aims to get to know more about what culture is used in a country so that the law can

\footnotetext{
5 Bambang Heriyanto, "Tata Cara Pelaksanaan Uang Paksa dan Sanksi Administratif di PTUN (Sumbangan Pemikiran)", Hukum Online, March 19, 2021, accessed from Hukumonline.com/berita/baca/hol21127/tata-cara-pelaksana-finance-forced-and administrativesanctions-for-contribution-of-thought.

${ }^{6}$ Adwin Tista, "Implikasi Pengawasan Terhadap Produk Hukum Yang Berbentuk Keputusan Tata Usaha Negara Melalui Peradilan Tata Usaha Negara (Analisis Politik Hukum Terhadap UndangUndang Nomor 5 Tahun 1986 Junto Undang Undang Nomor 9 Tahun 2004 Junto Undang-Undang Nomor 51 Tahun 2009 Tentang Perubahan Kedua Undang-Undang Peradilan Tata Usaha Negara", Al Adl ', Volume 7 Number 13, 2015, p. 6.

${ }^{7}$ Lawrence M. Friedman, “On Legal Development”, Rutgers Law Review, Volume 24 Number 1, 1969, p. 225.

8 Shidarta, “Apa Itu Budaya Hukum?", Binus University Faculty Of Humanities, March 23, 2021, accessed from https://business- law.binus.ac.id/2019/10/04/apa-itu-budaya-hukum/.
} 
run in society. ${ }^{9}$ From the society's legal culture, it can be seen how the development of law in the future, because changes in a law affect the society and affect the technology that supports the progress of society.

Indonesia is often represented as a cultural mosaic, pieces of culture glued together into a large and complete cultural painting labeled "national culture". Likewise with the legal culture. ${ }^{10}$ Cultural factors function as the formation of legal forms in their application in society. Because every nation has a history and that history can unite its people in that nation. If a society is considered, it will appear that even though the characteristics of the individual are different, the citizens will give the same reaction to certain symptoms. By having the same reaction, they have the same general attitude. The things that belong together in cultural anthropology are called culture. ${ }^{11}$

Thus, FC von Savigny, a legal expert from Germany, has this opinion. Legal culture is thick with the history of a nation. In this case, it is interpreted as a reflection of law in society and social life is a culture that has existed in their nation's history (Volksgeist). ${ }^{12}$ In this case, if it is related to the implementation of forced money and administrative sanctions on the defendant who did not carry out the injunction so far the decision has been carried out, namely the defendant who should have been declared defeated in court must carry out the decision by executing the verdict according to what the judge has decided. The effectiveness of enforcing forced money and administrative sanctions for state administration bodies or officials unwilling to implement court decisions has been described in Article 116 paragraph (4) and (5) of Law Number 51 of 2009 concerning State Administrative Courts. However, the law does not yet regulate in detail and clearly about implementing this forced effort. Especially in article 116 paragraph (7) of Law Number 51 of 2009 concerning State Administrative Courts, it explains that "Provisions regarding the amount of forced money, types of administrative sanctions, and procedures for implementing forced payments and/or administrative sanctions are regulated by statutory regulations legislation" but in reality, until now there is no statutory regulation that regulates the mechanism for implementing forced money and administrative sanctions. And there is no Government Regulation or institution of imperative authority for judges or authority over state

9 Ika Darmika, "Budaya Hukum (Legal Culture) dan Pengaruhnya Terhadap Penegakan Hukum di Indonesia", Journal of tô-râ Law, Volume 2 Number 3, 2016, p. 5.

10 Syafruddin Makmur, "Budaya Hukum Dalam Masyarakat Multikultural", Salam; Jurnal Sosial dan Budaya Syar'i, Volume 2 Number 2, 2015, p. 284.

11 Muh. Sudirman Sesse, "Budaya Hukum dan Implementasinya Terhadap Pembangunan Hukum Nasional". Jurnal Hukum Diktum, Volume 11 Number 2, 2013, p. 172.

12 Shidarta, “Apa Itu Budaya Hukum ?", Binus University Faculty Of Humanities, March 23, 2021, accessed from https://business- law.binus.ac.id/2019/10/04/apa-itu-budaya-hukum/. 
administrative courts to carry out executions related to the results of the PTUN decision and the forced attempts and administrative sanctions.

The defendant should implement the judge's decision, which has permanent legal force to create general principles of government (AAUPB). A good AAUPB is ethics in running good governance, Sjahran Basah said that government regulations are provisions that will be implemented by the society. ${ }^{13}$ Therefore, this provision must be following the legal culture that has existed in society for a long time. Law in society grows together with culture and becomes a legal culture that has been inherent for a long time. Therefore, a good AAUPB is needed to carry out a legal culture in society. Therefore, the legal culture in Indonesia needs to improve regulations so that the legal function is clear, namely for the benefit and legal certainty for the society and includes guarantees of legal protection for people who have disputes with State Administrative Decrees (KTUN) with state administrative officials/entities.

\section{B. Legal Offers to State Administrative Courts in the Implementation of Supervision on Legitimate Decisions to Achieve Legal Certainty and Legal Protection}

According to the explanation of the meaning conveyed by Lawrence M. Friedmen about legal culture, the author connects with a theory of legal philosophy, positivism and epistemology in law. Epistemology provides an overview of the way science describes the form of scientific activity in the scientific field. It means that the philosophy of law in the theory of epistemology explains the essence of the appropriate method of obtaining knowledge and this theory provides answers to scientific questions of the object being studied or researched. In other words, epistemology is a theory that seeks truth in science. ${ }^{14}$

In epistemological theory, to get the truth in research, you must know the characteristics of what will be studied in this science. Meanwhile, the theory of positivism by Hans Kelsen is that law is an order that forces human behavior (law is a coercive order of human behavior).

Then Prof. Herbert Lionel Adolphus Hart argues that positivism theory is distinguished in contemporary legal science. The rule of law is closed logic,

\footnotetext{
${ }^{13}$ Sjachran Basah, Eksistensi dan Tolok Ukur Badan Peradilan Administrasi di lndonesia, Alumni, Bandung, 1988, p. 13.

${ }^{14}$ Dani Habibi, "Perbandingan Hukum Pengadilan Tata Usaha Negara dan Verwaltungsgerecht Sebagai Perlindungan Hukum Rakyat", Kanun Journal of Legal Studies, Volume 21 Number 1, 2019.
} 
where the nature of the law in decisions can be obtained logically and morally according to the legal objectives it has and wants to achieve. ${ }^{15}$

John Austin argues that law can be called law if there are:

1. Sovereign;

2. Command;

3. Obliged to obey it (duty);

4. Sanctions for not complying with these regulations (sanctions).

Apart from being viewed from the aspects of epistemology and positivism, in terms of implementing these sanctions, the axiological basis also becomes the basis for discussion to find values related to scientific activities. Apart from the value of truth, it needs to be realized that various uses can be found in science as implications. ${ }^{16}$ Axiology emphasizes the function of carrying out studies by stating what objectives to be achieved and the useful value of the knowledge obtained. Furthermore, Muhadjir conveyed the benefits of axiology to achieve a more prospective future. Axiology understands the nature of the value of the usefulness of science by describing it through the various values that exist. ${ }^{17}$

Djalali said that the value in question is the value of truth, decency, goodness, and beauty, for example (1) A thing has value, means it is useful economically, politically, psychologically, and culturally, (2) A thing has value, means it has truth from the point of view, or contains truth from a moral and religious standpoint, or ethically, or aesthetically beautiful, (3) A thing has value, means having certain characteristics and qualities that cause people to have the desire to approve and accept it, (4) A thing contains a value, means responding to what is meant as something desired according to certain value criteria. ${ }^{18}$

In axiology, the study of the formation of the PTUN execution supervisory agency or an institution with authority to submit demands, provides a reference for understanding the reality that occurs, namely the cause of public dissatisfaction with the implementation of the execution of the PTUN decision. In order to make government policy, it is hoped that this study can provide an overview in creating a supervisory agency or additional authority for the execution of sanctions against defendants who do not want to carry out their verdicts.

\footnotetext{
${ }^{15}$ Sudiyana and Suswoto, "Kajian Kritis Terhadap Teori Positivisme Hukum Dalam Mencari Keadilan Substantif", Jurnal Ilmiah Ilmu Hukum QISTIE, Volume 11 Number 1, 2018, p. 107.

${ }_{16}$ Paulus Wahana, Filsafat Ilmu Pengetahuan, Pustaka Diamond, Yogyakarta (ID), 2016, p. 6.

${ }^{17}$ Muhadjir, N, Filsafat Ilmu: Positivisme, Postpositivisme, dan Postmodernisme, Sarasin, Yogyakarta (ID), 2001.

${ }^{18}$ M As'ad Djalali, Filsafat Ilmu: Suatu Pengantar, Alumni, Bandung, 2015.
} 
From this explanation, the authors provide a legal offer to the legal system of state administrative justice, namely the existence of an imperative authority that is given and must be carried out by the PTUN in supervising the results of the judicial decisions. So, the sanctions that should have been implemented by the defendant could be implemented properly. Because in the theory of positivism, namely regulations were originating from the government, the central government should think about this authority over the implementation of the PERATUN to guarantee legal objectives, namely legal certainty which is carried out under the supervision of the legal decisions of the PERATUN.

So even though the sanctions are regulated in Article 116 paragraph (4) and (5) Law Number 51 of 2009 concerning State Administrative Courts already exist, implementation system for supervision and execution of the decision has not been explained yet to how the system works. Following the theory of legal philosophy of epistemology in essence, the method used must be relevant and must answer questions in science. So, this knowledge can be applied to the right way to obtain the truth. In a constitutional state, the state is the guarantor of legal welfare based on the national and democratic nature of the constitution, so the constitution can be said to be national in character if it's based on awareness in law and the state. So it is clear, the responsibility of the imperative authority at the state administrative court will eventually end up with the president as the central government. So, in Article 116 paragraph (6) of Law Number 51 of 2009 concerning State Administrative Courts explains that decisions that are not implemented by state administration officials are reported directly to the central government are considered ineffective. There should be an authority in the supervision and execution of the PERATUN before going to the central government. Simply put, the central government is the last resort in overcoming this problem.

With the promulgation of Law Number 30 of 2014 concerning Government Administration which in this regulation provides broader authority to the PERATUN in resolving state administrative disputes. This intersects because of the legal material that provides an extension of authority to the PTUN, but the formal laws governing the PTUN have not been revised so that there is a legal vacuum because the process of the formal legal justice system has not been adjusted to existing legal materials. So, there is no legal certainty regarding the exercise of the authority of forced money and administrative sanctions on the defendant who does not implement the verdict which has permanent legal force. The purpose of making and the position of PTUN in a country must be related to the philosophy of the 
country it adhered to. The Republic of Indonesia is a constitutional state based on Pancasila and the 1945 Constitution. Therefore, the rights and interests of individuals are upheld the same as the rights of society in general. Individual interests are the same as the public interest or public interest. ${ }^{19}$

The author takes the example of a country that has a lot of legal scientists there, Germany. Germany has a body of control that applies to a government sued to PERATUN by an individual or a civil law entity. So, the decisions that will be carried out from the trial results can be implemented following the applicable regulations by prioritizing the people's interests. ${ }^{20}$ Indonesia can still follow the German state in terms of adding authority or institutions as supervision of the results of executions stipulated in the results of the judiciary applies in Indonesia at the PTUN. So, from the example of the German Administrative Court legal system, it can be an example of the implementation of legal benefits and legal certainty in the system of implementing legal decisions and the implementation of administrative sanctions and forced money on the defendants, bodies, or TUN officials.

\section{CONCLUSION}

Indonesia and Germany, namely in various courts in Indonesia it ends in the Supreme Court as the highest court, in contrast to Indonesia in Germany they have each Supreme Court for various related issues, such as the Bundesverwaltungsgericht which is none other than the pinnacle of the PTUN in Germany. In Germany there is a supervisory body over the Government and the implementation of prosecution against the government, and it can be brought to trial to be a different concept, meanwhile the concept is not adopted by Indonesia. Just like the legal concept in Germany between formal law (judicial system law) and material law (both theories of State Administration law) are interrelated in resolving cases in court, this is used as a basis. Meanwhile, in Indonesia, although formal law (PTUN Law) was formed, material law was only formed in 2014. So, before 2014 there was no legal or theoretical basis for resolving state administrative disputes in Indonesia. The idea of establishing an institution which is the idea of German state with an expansion of authority or power of the PTUN with the issuance of Law Number 30 of 2014 concerning Government Administration allows this institution to be free from intervention from any institution and as a complement to the PTUN both in the process of society assistance or legal

\footnotetext{
${ }^{19}$ Hendrik Salmon, "Eksistensi Peradilan Tata Usaha Negara (PTUN) Dalam Mewujudkan Suatu Pemerintahan Yang Baik", Jurnal Sasi, Volume 16 Number 4, 2010, p. 18.

${ }^{20}$ Dani Habibi, "Perbandingan Hukum Pengadilan Tata Usaha Negara dan Verwaltungsgerecht Sebagai Perlindungan Hukum Rakyat”, Kanun Journal of Legal Studies, Volume 21 Number 1, 2019. p. 16.
} 
subjects in the litigation process at PTUN until the implementation process of court decisions which have permanent legal force. So, the concept of legal justice against society in the public sector can be realized. The supervision of PTUN over state administrative decisions which are passed by the judge to the defendant who is the object of the state administrative court indicated that the system has not yet completed in its implementation after the issuance of the PERATUN decision. Therefore, it is necessary to have absolute competence in the PERATUN to supervise and execute the decisions so that they can be implemented by the defendants, state administrative bodies or officials to be more effective. Achieving legal certainty and guaranteed protection for justice seekers (yustisiabellen) must be done to achieve a just law. So that the achievement of a rule of law and a good PERATUN system will provide good output in its implementation and for the $r$ ealization of the General Principles of Good Governance in the implementation of the verdict of the defendant. So, it can be concluded, the legal offers that can be made are: (1) Providing imperative authority for PTUN so that the decision of the Administrator has executorial power; (2) The imposition of coercive measures through government regulations regulating instructions for implementing decisions in imposing forced attempts as well as administrative sanctions through regulations from a circular letter of the Supreme Court; (3) Addition of material content to the application of forced money, such as what types of decisions can be subject to forced money sanctions, for who forced money is imposed, how much is the exact amount of forced money that can be imposed in the ruling against the defendant who does not carry out the decision, and when the commencement of enforced money is enforced; (4) Addition of material content to the administrative sanctions such as specific explanation to the sanction that imposed and to whom the order for the imposition of administrative sanctions is ordered.

\section{DECLARATING OF CONFLICTING INTEREST None}

\section{FUNDING INFORMATION None}

\section{ACKNOWLEDGEMENT}

The author expresses gratitude to Allah SWT who has given the author the knowledge that hopefully can be helpful for society. With this paper, the authors hope to contribute knowledge to the country and nation. Do not 
forget the author would like to thank the author's parents, who have supported and understood how the author could learn well and study and pass it on through writing. The author's gratitude also goes to the good people who support the author to be motivated in making this paper.

\section{REFERENCES}

Arifin, R., Waspiah, W., \& Latifiani, D. (2018). Penulisan Karya Ilmiah untuk Mahasiswa Hukum. Semarang: BPFH UNNES.

Basah, S. (1988). Eksistensi don Tolok Ukur Badan Peradilan Administrasi di Indonesia. Bandung: Alumni.

Darmika, I. (2016). Budaya Hukum (Legal Culture) dan Pengaruhnya Terhadap Penegakan Hukum di Indonesia. Jurnal Hukum tô-râ, 2 (3), 5.

Djalali, M. A. (2015). Filsafat Ilmu: Suatu Pengantar. Bandung: Alumni.

Friedman, L. M. (1984). American Law: An Introduction. New York: WW Norton \& Co.

Friedman, L. M. (1969). On Legal Development. Rutgers Law Review, 24 (1), 225.

Habibi, D. (2019). Perbandingan Hukum Pengadilan Tata Usaha Negara dan Verwaltungsgerecht Sebagai Perlindungan Hukum Rakyat. Kanun Jurnal Ilmu Hukum, 21 (1). 16.

Imaniyati, N. S. (2003). Pengaruh Paradigma Positivisme Terhadap Teori Hukum Dan Perkembangannya. 19 (3).

Lask, Radbruch, \& Dabin. (1950). The Legal Philosphies of Lask, Radbruch, and Dabin. Translate by Kurt Will, etc. Massacilusetts: Harvards University press, Cambrigg.

Makmur, S. (2015). Budaya Hukum Dalam Masyarakat Multikultural. Salam; Jurnal Sosial dan Budaya Syar'i, 2 (2), 284.

Maridjo. (2016). Pengawasan Peradilan Tata Usaha Negara Terhadap Keputusan Tata Usaha Negara Dalam Mewujudkan Pemerintahan yang Baik. Semarang: Universitas, Semarang.

Muhadjir, N. (2001). Filsafat Ilmu: Positivisme, Postpositivisme, dan Postmodernisme. Yogyakarta (ID): Sarasin.

Hukum Online. (March, 2009). “Procedures for Implementing Compulsory Money and Administrative Sanctions at PTUN (Thought Contribution)", Hukum Online, March 19, 2021, accessed from https://hukumonline.com/berita/baca/hol21127/tata-cara-pelaksanauang-paksa-dan-sanksi-administrative-di-ptun-sumbangan-pemikiran.

The Republic of Indonesia. (2014). Law Number 30 of 2014 concerning Government Administration.

The Republic of Indonesia. (1986). Law Number 5 of 1986 concerning State Administrative Courts. 
The Republic of Indonesia. (2009). Law Number 51 of 2009 concerning State Administrative Courts.

Salmon, H. (2010). Eksistensi Peradilan Tata Usaha Negara (PTUN) Dalam Mewujudkan Suatu Pemerintahan Yang Baik. Jurnal Sasi, 16 ( 4 ), 18.

Sesse, M. S. (2013). Budaya Hukum dan Implementasinya Terhadap Pembangunan Hukum Nasional. Jurnal Hukum Diktum, 11 (2), 172.

Shidarta. (March, 2019). "What is Legal Culture ?", Binus University Faculty Of Humanities, March 23, 2021, accessed from https://businesslaw.binus.ac.id/2019/10/04/apa-itu-budaya-hukum/.

Sudiyana \& Suswoto. (2018). Kajian Kritis Terhadap Teori Positivisme Hukum Dalam Mencari Keadilan Substantif. Jurnal Ilmiah Ilmu Hukum QISTIE, $11(1), 107$.

Taufiq, M. (2014). Keadilan Substansial Memangkas Rantai Birokrasi Hukum, First Edition. Yogyakarta: Pustaka Pelajar.

Tista, A. (2015). Implikasi Pengawasan Terhadap Produk Hukum Yang Berbentuk Keputusan Tata Usaha Negara Melalui Peradilan Tata Usaha Negara (Analsis Politik Hukum Terhadap Undang-Undang Nomor 5 Tahun 1986 Junto UndangUndang Nomor 9 Tahun 2004 Junto UndangUndang Nomor 51 Tahun 2009 Tentang Perubahan Kedua UndangUndang Peradilan Tata Usaha Negara). Al Adl', 7 (13), 6.

Umanailo, M Chairul Basrun. (2016). Positivisme- Positivisme- Post Positivisme. Jurnal Filsafat Hukum Universitas Indonesia Vol 3.

Wahana, P. (2016). Filsafat Ilmu Pengetahuan. Yogyakarta (ID): Pustaka Diamond. 


\section{ABOUT AUTHOR(S)}

Mutiara Hamdalah Munandar, born in Tasikmalaya, West Java on February 5, 1999, is a student of the Faculty of Law, State University of Semarang. Achievements in the field of writing that have been obtained are 2nd place in the National Essay Competition at UIN Sunan Kalijaga Yogyakarta, 2nd place in LKTI at UIN Sunan Ampel Surabaya, and Best LKTI Presentation at Sultan Ageng Tirtayasa University, Banten. Active in several intra-campus organizations, namely UKM Lex Scientia, Faculty of Law as Head of Advocacy and BEM FH UNNES as staff of the Ministry of Research and Women's Empowerment. Mutiara is active in several external organizations, namely Indonesian Youth Space as President.

Yudha Chandra Arwana, born in Ngawi, East Java on April 28, 2000, is a student at the Faculty of Law, State University of Semarang. Participate in off-campus community activities that are engaged in social and cultural fields, namely the Indonesian Youth Space Community, as staff of the Information \& Relations Department division. Activities or competitions that have been followed include Finalists Passing Funding for the Essay Competition of the Social Life of the People of Central Java (Lensa Mata) and Presenters at the 3rd International Conference on In Indonesian Legal Studies.

Asna Yusrina, born in Jakarta, August 19, 1996, is a student of the Creative of Multimedia Faculty of Advertising Design Multimedia University, Melaka Malaysia. Asna loves writing since she was a freshman. In addition, Asna is active in several external organizations, namely the World Indonesian Student Association. As a deputy program coordinator for the Adiwangsa Program, SubSector of Education-Community Service, Directorate of Movement and Community Service World Indonesian Student Association. Currently, Asna is carrying out her final year project for an advertising brand campaign. 